\title{
Strengthening Climate Change Adaptive Capacity of Rural Women Crop Farmers through Reduced Social Exclusion in Nigeria
}

\author{
C. C. Ifeanyi-Obi and A. Henri-Ukoha
}

\section{ABSTRACT}

\begin{abstract}
Climate change has continued to exert devastating effects on the Nigerian agricultural sector. Consequently, several efforts are made to adapt the agricultural sector to these effects of climate change, but the expected results are yet to be achieved. Much of the research on challenges to climate change adaptation were done without considering gender perspective. This review in effort to contribute to addressing this gap reviewed 1.) the climate change adaptation strategies used by rural women crop farmers in Nigeria, 2.) challenges to climate change adaptation among rural women crop farmers and 3.) social exclusion and influence on agricultural activities and climate change adaptation among rural women crop farmers in Nigeria. The study further suggests ways of eradicating social exclusion of rural women farmers with a view to strengthen their climate change adaptive capacity in the country. From the lessons highlighted, suggestions are made to make adaptation to climate change more gender-responsive, effective, and successful.
\end{abstract}

Keywords: Climate change, adaptive capacity, social exclusion, eradication, rural women, crop farmers.
Submitted: December 13, 2021

Published: January 24, 2022

ISSN: $2684-1827$

DOI: 10.24018 /ejfood.2022.4.1.436

\section{C. Ifeanyi-Obi*}

Department of Agricultural Economics and Extension, Faculty of Agriculture, University of Port Harcourt, Rivers State, Nigeria.

(e-mail: clara.ifeanyi-obi@ ${ }^{\circledR}$ uniport.edu.ng) A. Henri-Ukoha

Department of Agricultural Economics and Extension, Faculty of Agriculture, University of Agriculture, University of Port Harcourt, Rivers State, Nigeria.

(e-mail: adanna.henri-ukoha@uniport.edu.ng)

*Corresponding Author

\section{INTRODUCTION}

Climate change and gender inequality are among major threats ravaging contemporary society [1], [2]. Countries (e.g., Nigeria) that contribute least to greenhouse gas (GHG) emissions suffer most the effects of climate change due to their low infrastructural capacity. The agricultural sector is most hit by this change in climate as a result of high dependence on rain-fed agriculture heightened by low infrastructural capacity of farmers. The sector remains the largest sector of Nigerian's economy, employing two-thirds of the entire labour force (Food and Agriculture Organisation (FAO), Nigeria at a glance, n.d). The increasing impact of climate change among other challenges (outdated land tenure system, low level of irrigation, poor access to credit facilities, heavy post-harvest losses, gender inequalities with respect to access to opportunities and resources and poor researchextension-farmer linkages) [3]-[5] on the agricultural sector continues to reduce the effectiveness of the resources and man power invested in the sector leading to inability for the country to attain the SDGs of zero hunger and no poverty. Adaptation remains the most effective way of handling climate change effects since most of the natural occurrences leading to climate change cannot be controlled by man. To achieve significant result in climate change adaptation, a holistic and comprehensive approach that addresses not just the effects but acknowledges challenges to adaptation as well recognizes the fact that farmers are not a homogenous group must be followed [6], [7]. It is noted that majority of the study relating to agriculture and climate change in Africa (Nigeria inclusive) concentrated on impacts and corresponding adaptation/coping strategies as well as projections with less attention given to challenges of climate change adaptation [7], [8]. These incomplete assessments are not suitable enough to give the needed insight that will inform and guide policies to achieve best practices. The peculiarities of every group (men, women, youths, children, farmers based on farming enterprise, farmers based on geographic location) must be taken into consideration in order to plan adaptation path that can effectively address climate change effects in the country.

Women play significant role in agricultural development in Nigeria accounting for a substantial share of the labour force thus contributing to sustaining the country's economy [9], [10]. Ironically, despite the significant contributions of women to agriculture in the nation, they still face numerous difficulties in accessing natural resources, securing proper ownership, knowledge, service, and opportunities [11], [12]. For instance, $60-79 \%$ of rural work force is women but the men are five times more likely to own land [13]. The Nigerian National Gender Policy in Agriculture highlighted that gender inequalities limits agricultural productivity and effectiveness hence undermine development agenda. It emphasized that failure to recognize the different roles of women will result in misguided projects and programmes. Currently, even in the face of many limitations, women are taking larger and more defined roles on farms and in agribusiness. Increasing number of women are becoming key leaders in farm operations. The contributions of women in the agricultural sector could be much better if they have equal 
access to essential farm inputs, resources, and services [14]. FAO [15] stated that one of the reasons why Agriculture is underperforming in many developing countries is the fact that women lack the resources and opportunities they need to make the most productive use of their time. It went further to explain that women are farmers, workers, and entrepreneurs, but almost everywhere they face more severe constraints than men in accessing productive resources, market, and services. Even when government manage to enact gender-responsive policies, implementation is frustrated by non-compliance of parties involved and strong attachment to cultural beliefs and practices. Rural areas in Nigeria are known for strong inclinations to cultural beliefs and practices which mostly neglects the place of women in decision making and access to information and resources. For instance, observation has shown that in mixed community associations, leadership positions are given to men even when a woman is more talented to handle the position.

It is important to note that the vulnerability of agriculture is not only determined by the nature and magnitude of environmental stress like climate change, but by the combination of societal capacity to cope with and/or recover from environmental change [16]. Against this forgoing backdrop, this study reviewed the climate change adaptation strategies used by rural women crop farmers in Nigeria, challenges to climate change adaptation among rural women crop farmers, social exclusion and influence on agricultural activities and climate change adaptation among rural women in Nigeria and ways of eradicating social exclusion of rural women farmers from access to information and resources with a view to strengthen their climate change adaptive capacity in Nigeria.

\section{METHODOLOGY}

The study reviewed challenges to climate change adaptation, social exclusion, influence of exclusion on both agricultural activities and adaptive capacity of rural women farmers in Nigeria and strategies for social exclusion eradication among rural women farmers with a view to promote inclusion in adaptation efforts using integrated review approach. This approach employed the use of information from both qualitative and quantitative research, scholarly and grey literature as well as allowed combination of perspectives from different fields [17]. This ensured broader insight to the concepts reviewed since climate change cut across different disciplines and areas. Articles reviewed were accessed from on-line scholarly and scientific databases particularly AGORA and AJOL. Other general search engines namely Google and Bing were also employed to allow for a more robust and general overview on the subject matter. Responsiveness to search terms and year of publication (publications not older than ten years but allowed earlier literature that gave fundamental insight to the concepts studied) were the major inclusion criteria.

Validity and reliability were ensured through the use of more than two reviewers and triangulation with other researchers, groups and expert consultants. Information gathered were categorized, analysed and synthesized based on the objectives of the study and presented in that order.

\section{Climate Change Adaptation Strategies USED by RURAL WOMEN CROP FARMERS IN NIGERIA}

Climate change is real, and several studies have concluded its impact on smallholder farming systems as well as poor rural households in developing countries who bear the brunt of the burden [18], [19]. Climate change threatens the sustainability of food production of rural communities in Sub-Saharan Africa that are dependent on rain-fed agriculture- Nigeria inclusive [20]. Climate change leads to losses in agricultural productivity, household food insecurity, low profits, income, and welfare of farm families [21]. Adaptation or mitigation responses are therefore required to withstand the devastating climate change impacts [22]. The climate change adaptation strategies employed by farmers is documented [23], [24]. Farmers in Nigeria are not left out of these actions. The responses of Nigerian farmers include changing crop variety, soil and water conservation [25]; use of crop rotation [26]; and intercropping/multiple cropping, agroforestry, mulching [27]. Alhassan et al. [28] as well as Solomon and Edet [29] reported change in planting dates as the most common adaptation strategy employed by farmers. Reduced burning of residue, zero tillage, mulching, mixed cropping, application of wood ash, tree planting, crop rotation and cover cropping were identified as the climate change adaptation strategies used by the farmers [30]-[34]. Anyaoha et al. [35] reported the use of engagement in complementary/diverse livelihoods, riverside bank cultivation, frequent weeding as climate change adaptation strategies.

Other climate change adaptation strategies used by farmers in Nigeria include increase in farm size, procurement of credit facilities to ensure their farm as well as procurement of other improved farm inputs, access to information from weather forecast stations, access to information from agricultural extension agents, increase fallowing to enable farm land replenish better, moving to better farm land, diversification of enterprise, use of improved/resistant species of crop and animals [36]-[40].

However, considering the significant role of gender in development, gender concerns should be mainstreamed in climate change research. Hence, research should focus on how gender groups, especially women, can adapt effectively to climate change [41]. This is evident in a study conducted on gender roles in climate change adaptation strategies by cassava-based farmers in Gokana Local Government Area of Rivers State. Henri-Ukoha et al. [30]-[32] reported the practice of change of time for land preparation, change of harvest dates and use of early crop maturing varieties. Adzawla et al. [42] reported the use of zero tillage and intercropping by female farmers while Assan et al. [43] identified the varying planting dates, crop diversification and use of improved crop varieties to adapt to climate change effects. This also reduced their vulnerability and enhanced their resilience to climate change impacts. This is evident in the fact that the already vulnerable societies, individuals, and classes are more vulnerable to the threats and impacts of climate change [44]. The generally high poverty levels among women also predispose them to severe climate impacts and reduce their adaptive capacities. Again, women being the custodian of food production need to put some measures in place to adapt to the changing climate. 


\section{Challenges to Climate Change Adaptation} AMONG RURAL WOMEN FARMERS IN NIGERIA

The challenges faced by rural women farmers in adapting to climate change is widely documented in literature. HenriUkoha [33], [34] reported that farmers cannot afford to procure the necessary inputs and resources required to practice adaptation in Southern Nigeria. In their work on challenges faced by cocoyam farmers in adapting to climate change in Southeast Nigeria, Ifeanyi-Obi et al. [7] reported that lack of and high cost of farm inputs and low soil fertility, land and labour, poor access to information and ineffectiveness of cooperatives, lack of/poor access to fund and credit facilities and poor government support, lack of improved varieties of cocoyam, poor value attached to cocoyam, poor infrastructural capacity and technology knowhow and transportation were the challenges faced by farmers in adapting to climate change impacts in Nigeria. Labour constraint may be as result of rural-urban migration particularly among youths as they seek for alternative sources of employment in the cities.

Male farmers have possession and control as to the decision to be made on most productive resources than the female farmers in developing countries, hence their adaptive capacities. This limits the women's ability to employ some effective climate change adaptation strategies. For instance, $62 \%$ and $74 \%$ of the female respondents make decision to sell small livestock and poultry, respectively in Nupe and Yoruba in Nigeria [45], [46].

However, Henri-Ukoha et al. [30]-[32] enumerated the challenges faced by the female cassava-based farmers in Gokana Local Government Area in practicing climate change adaptation strategies as irregular contact with agricultural extension agents, lack of access to improved cassava varieties and non-availability of credit facilities. The extension agents are supposed to teach the farmers how to use the effective adaptation practices, but when they are not available, the women are deprived of the information. Lack of access to and control over land, division of labour, marriage relationships, access to education and responsibility for dependents were the challenges faced by female farmers in Cameroun in adapting to climate change [47].

Though climate change affects all farmers, their level of vulnerability as well as capacity to adapt may differ hence require specific effort to properly address their needs. In same vein, Ifeanyi-obi et al. [38] in their study of socio-economic determinants of cocoyam farmer's strategies for climate change adaptation in Southeast Nigeria found that choice of adaptation strategies used by cocoyam farmers was influenced by age, gender, location of farmer, monthly income and labour. They explained that gender was a significant variable to consider in climate change adaptation plan since male and female farmers react differently to adaptation issues.

\section{Social Exclusion: MEANing AND EFFECTS ON AGRICULTURAL ACTIVITIES OF RURAL WOMEN CROP FARMERS IN NIGERIA}

Social exclusion is defined in varying ways by different people according to their context and peculiarities. Department for International Development (DFID) policy paper [48] described social exclusion as a process by which certain groups are systematically disadvantaged because they are discriminated against on the basis of their ethnicity, race, religion, sexual orientation, caste, descent, gender, age, disability, HIV status, migrant status or where they live.

The paper explained that social exclusion could be open and deliberate such as when institutions discriminate in their laws and policy; in most cases, it occurs unofficially. People become perpetuators of social exclusion unintentionally through their attitudes and disposition to others based on certain differentiating factors. Furthermore, people could be excluded based on different criteria for instance gender, ethnicity, race, disability etc. This makes social exclusion a general sociological problem as it could be found in almost every facet of human socialization. Beall and Piron [49] identified diversity of definitions and views in their study of social exclusion. The respondents to the study mentioned the concept of social exclusion as exhibiting one or more of the following characteristics:

- referring to individuals (e.g., through exclusion from labour markets) or categories and/or groups (e.g., caste or minority groups);

- being founded on a social relations approach, concerned not only with the excluded but also the excluders, thus putting power at the centre of the analysis

- including an institutional dimension involving organisations and processes that exclude (e.g., some citizens being left out of decision-making processes);

- having a causal dimension allowing, for example, a focus not only on poverty but also the factors leading to poverty and other forms of social disadvantage (e.g., racial prejudice or religious intolerance leading to lesser access to education or the job market); and

- involving a multidimensional process that intersects with other aspects of social disadvantage such as poverty or gender discrimination (e.g., gender or ethnic and religious minority status).

These characteristics shows social exclusion as both a process and an outcome of a process, that is a state. It could be a state in which an excluded individual cannot participate wholly in activities or a process that excludes an individual from fully participating in their community activities. Similarly, Silver [50] describes social exclusion as a multidimensional process that precludes full participation in the normatively prescribed activities of a given society as well as denies access to information, resources, sociability, recognition, and identity, eroding self-respect and reducing capabilities to achieve personal goals. Precisely, social exclusion in the context of this paper refers to all activities and processes that denies rural women equal opportunity to participate in social, economic, political, and cultural life in their rural community. It portrays social exclusion as a mitigating factor to the effectiveness of rural women farmers.

Ifeanyi-obi and Ugorji [51] in their study of effects of social exclusion on climate change adaptation of female arable crop farmers in Abia State, Nigeria found that the most prevalent form of exclusion suffered among female arable crop farmers were lack of access to credit facilities and land ownership, denial to head groups and organisations, and unequal access to social services. 
Social exclusion promotes denial of women's access to information, opportunities and vital resources that could enhance their agricultural productivity. When women do not have access to basic information regarding agricultural inputs including improved farm tools and hybrids of different species, they continue to use crude technologies and poor yielding species of crops leading to low yields. In addition, having access to market information could be a viable way of ensuring demand-driven production, good sales as well as reducing post-harvest losses as farm products are sold out upon harvest. Adenugba and Raji-Mustapha [52] stated that rural women play pivotal role in producing staple crops, livestock, fisheries, forestry and in food-processing storage and marketing yet constrained by the burden of reproduction, asymmetric rights and obligations within the household, different role models, limited access to resources and information including land, credit, extension services and training and appropriate agricultural technology.

Land is a very crucial farm resource without which there would be no agricultural production [45], [46]. The author noted that the major economic constraint for most rural women is the lack of land ownership. Many cultures do not allow women direct access or ownership to land hence are usually bound to a large extent by the decision of the landowner. Ownership to land is done mostly by inheritance with only men being entitled to own land resources. In addition, high level of illiteracy among the women folk limits their access to other productive farm resources hence their inaccessibility to information, available on-farm resources and improved technological innovations that can impact positively on farm their productivity and efficiency.

Different assumptions and claims as regards the level of increase in productivity that could arise if women are given access to basic resources and opportunities abound. The FAO State of Food and Agriculture Report in 2010-11 noted that if women are given same level of access to productive resources as men, they could increase yields on their farms by 20-30 percent. It explained that this could raise agricultural productivity in developing countries by $2.5-4$ percent, hence reduce the number of hungry people in the world by $12-17$ percent. This shows that women access to resources could be a viable way of improving agricultural production

FAO and ECOWAS Commission [11] stated that the problem of inadequate agricultural and rural development in Nigeria is not caused by paucity of ideas and plans, nor insufficient funding of programmes, it is mainly the result of insufficient attention to gender, corruption and embezzlement of funds, coupled with the adoption of a top-down approach to programme development and the absence of a reliable sex disaggregated database. The report identified six critical resources that women lack access to and control, namely; land, training, inputs/technologies, equipment, water and health facilities and further noted the major reasons for the persistence of this gender inequalities to include: cultural and societal values; low level of education and sensitization; religious beliefs; high level of poverty among women; poor implementation of gender policies; lack of continuity and sustainability of development programmes; early marriage, etc.

Ifeanyi-obi, Olatunji and Akpala [14] identified the effects of social exclusion on agricultural activities of rural women in Ahoada LGA of Rivers State in Nigeria to include denial of access to agricultural information and ownership of agricultural assets and limitation of participation in decision making process in community.

\section{INFLUENCE OF SOCIAL EXCLUSION ON CLIMATE CHANGE ADAPTATION OF RURAL WOMEN FARMERS}

In the rural setting, women constitute a significant proportion of the active labour force in the agricultural sector [52]. Unfortunately, they face numerous constrains in trying to adapt their farming system to the effects of climate change. This is due to the fact that they experience limited access to information and resources that will facilitate the adoption of available adaptation strategies. A critical look at most of the adaptation strategies used by farmers in Nigeria highlights that access to land, credit facilities, information/advisory services and taking leadership roles in farmers associations are indispensable resources for effective adaptation. Ironically, social exclusion limits women access to these important resource for climate change adaptation. Effective and successful climate change adaptation cannot be achieved unless the basic resources and opportunities needed are provided. For instance, most rural community associations are headed by men, even though membership comprises women, they are not adequately represented in leadership positions hence decision and policies made do not address their interest and needs. In addition, most tradition in Nigeria do not support land ownership by women making adaptation option that demands increase in farmland difficult for women to adopt. Furthermore, women are overrepresented in unpaid, seasonal, and part-time work, and are often paid less than men, for the same work [15]. This contributes to low income generating power of rural women. Without sufficient fund or access to credit facilities, it will be difficult for rural women to adopt most of the climate change adaptation measures available as most of them are capital intensive e.g., procurement of improved varieties of crop and livestock, herbicides, and pesticides.

Ifeanyi-obi and Ugorji [51] found the major effects of social exclusion on climate change adaptation of female arable crop farmers in Abia State, Nigeria to include lack of access to necessary resources (particularly improved farm inputs and extension services), technologies and credit facilities required to support their farming activities to overcome climate risks and threats, lack of ownership to farmland for increased size, limits participation in climate change discourse that could positively impact their adaptation capacity and discouragement from investing in adaptation action.

\section{ERADICATING SOCIAL EXCLUSION AMONG RURAL DWELLERS IN NIGERIA}

The detrimental effects of social exclusion to the agricultural productivity of rural women are numerous. Reducing all forms of exclusion to the barest minimum will greatly enhance the productivity of these rural women hence improved standard of living for rural household.

Eradicating social exclusion starts with proper awareness and knowledge of social exclusion and its detrimental effects 
by all stakeholders in agriculture, community associations and even households. Onyekuru and Marchant, [53] noted that awareness is a prerequisite to readiness to adapt to a change. Greater awareness and understanding of social exclusion and its negative effects will motivate rural dwellers readiness to commit to eradication efforts. There is need for all stakeholders especially the men folk in the rural areas to understand that social exclusion does not only limit women's productivity but negatively impacts the overall living standard of the rural household. This will stimulate their commitment to practices that support inclusion of women in essential positions and platforms. Traditional rulers, Religious and community leaders will through this sensitization understand the need to eliminate negative traditional and religious beliefs and practices that distorts the participation and development of women in the rural areas.

Capacity building of rural women is an important tool to eradicate social exclusion. It is important for women to possess the required capacity to command more participation in rural community activities and associations. Developing their leadership skills and capacity will equip them to hold leadership positions and work effectively. Increased skill acquisition and empowerment programme, training and seminar by government and intervention agencies will contribute to enhancing rural women's capacity.

Timely access to information, resources and opportunities are indispensable to eradication of social exclusion in rural areas. Information is a very vital tool for decision making. When women have access to timely information, they will be equipped to take the needed decisions and actions that will improve their farming activities. Formation of rural women associations and strengthening partnerships between already existing ones will not only facilitate information sharing among women, but it also helps empower the productive activities of women through pooling their resources together to form formidable force and strong voice in activities of the rural areas. Women's needs are not always considered in the delivery of agricultural extension and advisory services in the rural areas [10]. These services are most times targeted at the male farmers with the misconception that women will get the information from their husbands at home. Even in the distribution of improved varieties of crops and livestock as well as other subsidized farm inputs, the male folk most times dominate such activities even when the woman is the major farmer in the household. Olatunji et.al. [10] in their study of extension coverage of female food crop farmers in Ogba/Egbema/Ndoni Local Government Area of Rivers State, Nigeria found that approximately $60 \%$ of women in the area were not even aware of agricultural extension services. Improving women access to relevant information and advisory services will demand conscious effort and commitment of all stakeholders both traditional rulers, intervention agencies and government (at all levels).

Gender sensitive and responsive approach in planning and implementing advisory services as well as intervention programme is a basic necessity in tackling social exclusion of women. These programmes and services need to be systematically planned to address the needs and concerns of the women farmers. Involving women representatives at all levels of planning and implementation of these services and programmes will aid in ensuring relevance and more commitment as well as overall gender-sensitivity.

Increased ownership of basic resources for production particularly land is fundamental to eradication of social exclusion of women. Land ownership in Nigeria is still dominated by men. Identifying platforms and partnerships for increased access to land and ownership among rural women will enhance their productive capacities and promote their involvement in activities that demands long duration access to land for example cash crop production

Wearing gender lens in developing all government agricultural intervention programmes as well as budgetary allocations at Federal, state, and local level is fundamental to social exclusion eradication. Gender perspective must be integrated in these activities to make them favourable to the women folk.

Most importantly, gender equality legislation and policies are very important if social exclusion of women will be eradicated in the country. Nigeria's gender equality policy aims to eradicate gender inequality in political participation, education, health and employment, enforce women's land rights and offer protection from gender-based violence. However, the Nigeria Gender and Equal Opportunities Bill, first introduced in 2010, has been voted down twice in the national assembly in 2016 and 2018 with the argument that the Bill's measures were in opposition to Nigeria's constitution as well as religious and cultural practices and customs [54]. The author noted that even though several pieces of legislation potentially favourable to women and girls have been passed at state level, they had little positive impact due to low awareness, enforcement, and implementation. Discrimination against women in access to information, justice, education, employment and enjoyment of land and property rights will not be eradicated without enacting laws and policies to mitigate it. This will ensure that all sectors commit to the fight against social exclusion of women.

Climate change adaptation requires both coordinated effort and holistic approach in order to be effective [7]. A process or system that fails to recognize the peculiarities of a major minority may not be able to effectively tackle climate change adaptation. Gender supportive policies and practices are needed for climate change adaptive efforts to yield the expected result.

\section{LESSONS LEARNT AND WAY FORWARD}

The impacts of climate change are not gender neutral, so strategies to address them cannot be gender neutral (United Nations Development Programme (UNDP), n.d). The fact that men and women have differing coping and adaptive capacities as well as different access to and control over resources which translate to both gender-differentiated vulnerabilities to the impacts of a changing climate and differentiated strengths to adapt to these changes makes the need for gender-responsive adaptation plans and intervention a pressing one. Climate change contributes in widening gender gap hence intensifies existing economic and social gender disparities. Observing gender dynamics in designing and implementing adaptation approaches will help to ensure sustainability and greater impact and as well strengthen gender equality. 
People have different adaptation needs, depending on their socio-economic factors and access to opportunities, responsibilities, and decision-making power. Institutional Institute for Sustainable development (n.d) opined that without understanding these dynamics, which are often influenced by gender, it is possible to overlook the people with the greatest need for adaptation in adaptation plans.

From the foregoing, climate change is real and farmers in SSA (Nigeria inclusive) have employed some measures to adapt to the devastating impacts. It is necessary to view these adaptation strategies with a gender lens for greater impact. Women in Nigeria are victims of social exclusion depriving them of access to information, opportunities and vital resources that could enhance their agricultural productivity. This also deprives them of the requisite productive and financial resources for employing climate change adaptation strategies.

Developing the capacity of the women crop farmers in climate change adaptation strategies will help facilitate a gender responsive climate change action in the country as this will ensure greater participation and representation of women in all facets of climate change adaptation actions.

It is important for government (at all levels) and relevant stakeholders to ensure that women are given access to productive and financial resources needed to boost their productivity. This will also equip them to employ the necessary climate change adaptation strategies, hence reducing their vulnerability to climate change impacts. Availability of funds will also enable farmers to make significant investments in climate change adaptation strategies.

More attention should be given to those climate change adaptation strategies employed by women farmers as they are the custodian of food production. Possible ways of enhancing them should be explored to facilitate more effective and successful adaptations.

Women should be mainstreamed in every aspect of agricultural production as to make it more gender responsive.

\section{CONCLUSION AND RECOMMENDATIONS}

This paper concludes that gender-responsive policies and practices are inevitable for a more successful and sustainable adaptation to climate change effects among women farmers.

It therefore recommends that lessons and way forward elicited in this paper should be given priority to make adaptation among women farmers successful. Specifically:

- More effort should be channeled by the Federal Government of Nigeria to the implementation of national frameworks and adaptation plan particularly, the gender components. Realizing this goal will in no small measure make adaptation to climate change in the country gender-responsive.

- The agricultural extension system in the country should take up more vigorously the task of capacity building of both extension agents and female farmers on climate adaptation. Existing Fortnightly meeting of the Agricultural Development Programme could be leveraged on to facilitate this among extension agents while ongoing intervention programmes for women farmers could be incorporate climate change knowledge and capacity building.

- Financial support and insurance scheme for climate change adaptation is paramount in this pursuit. The Federal ministry of agriculture must align with related and concerned ministries, departments, and agencies to build strategic synergy that will provide the needed financial support for successful adaptation among women farmers in Nigeria.

\section{ACKNOWLEDGEMENT}

"This work was funded by a Fellowship from the African Institute for Mathematical Sciences, www.nexteinstein.org, with financial support from the Government of Canada, provided through Global Affairs Canada, www.international.gc.ca, and the International Development Research Center, www.idrc.ca"

\section{REFERENCES}

[1] Climate transparency report. Nigeria's country profile. 2020 https://www.climate-transparency.org/media/nigeria-country-profile2020 .

[2] National Action Plan on Gender and Climate Change for Nigeria. Department of Climate Change, Federal ministry of Environment 2020. www.climatechange.gov.org

[3] Oni T.O. Challenges and prospects of Agriculture in Nigeria; The way forward. Journal of Economic and sustainable development, 2013;4(10): 37-46

[4] Abutu O.P. Challenges of agriculture in Nigeria economy; A bane to food security. IOSR Journal of Agriculture and Veterinary Sciences, 2014;7(5): 18-21.

[5] Uche C., Ifeanyi-obi C.C. \& Wilcox G.I. An assessment of constraining factors in selected Agricultural activities in the coastal regions of the Niger Delta, Nigeria. International Journal of Agriculture and Rural Development, (IJARD), 2019;22(1):3867-3870.

[6] Enete A. A. Challenges of agricultural adaptation to climate change: The case of cassava post-harvest in Southeast Nigeria. International Journal of Climate Change Strategies and Management, 2013;5(4), 455-470. https://doi.org/10.1108/IJCCSM-08-2012-0045.

[7] Ifeanyi-obi C.C., Togun A.O., Lamboll R., Adesope O.M. \& Arokoyu S.B. Challenges faced by Cocoyam Farmers in adapting to climate change in Southeast Nigeria. Climate Risk Management, 2017;(17):155-164. https://doi.org/10.1016/j.crm.2017.04.002.

[8] Antwi-Agyei P., \& Stringer L.C. Improving the effectiveness of agricultural extension services in supporting farmers to adapt to climate change: Insights from northeastern Ghana, Climate Risk Management, 2021;32;100304

[9] Chandy P. The Role of Women in Agriculture. World Farmers Organization (WHO). FAO-Viale Delle Tenme di Caracalla, Malaysia Room Italy. 2012. Global Research Team. Retrieved from http://www.Ica.Coop/en/events-60 on 6/1/2012.

[10] Olatunji S.O. Ifeanyi-obi C.C. \& Etuk U.R. Extension Coverage of Female Food Crop Farmers in Ogba/Egbema/Ndoni Local Government Area of Rivers State, Nigeria. International Journal of Applied Agricultural Research, 2015;10(1):7-16.

[11] Food and Agriculture Organisation (FAO) and Economic Community of West African States (ECOWAS). National Gender Profile of Agriculture and Rural Livelihoods - Nigeria. Country Gender Assessment Series, Abuja. 2018, 92 pp

[12] Food and Agriculture Organisation (FAO). Good practices for integrating Gender equality and women's empowerment in climate$\begin{array}{lll}\text { smart } & \text { Agriculture } & \text { Programmes. }\end{array}$ http://www.fao.org/3/ca3883en/ca3883en.pdf Retrieved Feb 2020.

[13] Gender in Nigeria Report. Improving the lives of girls and women in Nigeria. 2012.

https://www.britishcouncil.org/sites/default/files/british-councilgender-Nigeria2012.pdf.

[14] Ifeanyi-obi C.C., Olatunji S.O. \& Akpala J. Effects of Social Exclusion on Agriculture Activities of Rural Women in Ahoada Agricultural Zone of Rivers State. Journal of Environmental Science, Toxicology and Food Technology, 2014;8(9):5-10. 
[15] Food and Agriculture Organization The role of Women in Agriculture. SOFA Team and Cheryl Doss. ESA Working Paper no 1-02 (March) FAO UN, 2011.

[16] Aryal J.P., Sapkota T.B., Khurana R., Khatri-chhetri A., Rahut D.B \& Jat M.L. Climate change and agriculture in South Asia: adaptation options in small holder production systems. Environ Dev Sustain, 2019. https://doi.org/10.1007/s10668-019-00414-4.

[17] Snyder H. Literature review as a research methodology: An overview and guideline. Journal of Business Research, 2019;104:333-339.

[18] Omerkhil N., Chand T., Valente D., Alatalo J.M \& Pandey R. Climate change vulnerability and adaptation strategies for smallholder farmers in Yangi Qala district, Takhar, Afghanistan. Ecol. Indicat., 2020;111:105863.

[19] Das M., Das A., Momin,S., \& Pandey R. Mapping the effect of climate change on community livelihood vulnerability in the Riparian region of gangatic plain, India. Ecol. Indicat., 2020;11, 106815

[20] Atube F., Malinga G.M., Nyeko M., Okello D.M., Alarakol S.P \& Okello-Uma I. Determinants of smallholder farmers adaptation strategies to the effects of climate change:Evidence from Northern Ghana. Agriculture and Food Security, 2020;10(6).

[21] Eze G.N., Ani A.O., Mathews-Njoku E.C., Anyanwu J.A \& Okoroma E.O. Crop farmers adaptation strategies to climate change in Abia state, Nigeria. Mid-East Journal of Agricultural research, 2019;8(3):947 953.

[22] Rosenzweig C., \& Solecki W. Action pathways for transforming cities Nature Climate Change, 2018;8(9):756-759. doi:10.1038/s41558-0180267-x.

[23] Douxchamps S., Van Wijk M.T. \& Silvestri S. Linking agricultural adaptation strategies, food security and vulnerability: Evidence from West Africa. Reg Environ Change 2016;16:1305-1317. https://doi.org/10.1007/s10113-015-0838-6.

[24] Soglo V.Y \& Nonvide G.M.A. Climate change perceptions and responsive strategies in Benin: the case of maize farmers. Climatic Change, Springer, 2019;155(2):245-256

[25] Yusuf M., Di Falco S., Deressa T., Ringler C. \& Kohlin G. The impact of climate change and adaptation on food production in low income countries: Evidence from the Nile Basin, Ethiopia, Ethiopian Development research Institute, 2008.

[26] Nwosu C.S., Onyeneke R.U., Joshua B.N., Nmagu C, J. \& Nwaodi K.T. Perception and adaptation to climate change by farm households in Etim Ekpo Local Government Area, Nigeria, Proceedings of the annual conference of the National Association of Agricultural Economists held at the Federal University of Technology, Akure, Nigeria, 24 to $27^{\text {th }}$ February, 2014, pp. 333-341.

[27] Enete A.A., Madu I.I., Mojekwu J.C., Onyekuru A.N., Onwubuya E.A. \& Eze F. Indigenous agricultural adaptation to climate change: study of South East Nigeria (ATPS Research Paper No.6), Nairobi, Kenya, African Technology Policy Network, 2011.

[28] Alhassan H., Kwakwa P. A \& Adzawla W. Farmers choice of adaptation strategies to climate change and variability in arid region of Ghana. Rev. Agric. Appl. Econ., 2019;22 (1):32-40.

[29] Solomon E. \& Edet O.G. Determinants of climate change adaptation strategies among farm households in Delta State, Nigeria. Current Investigation Agriculture Current Research, 2018;5 (3).

[30] Henri-Ukoha A. \& Adesope O.M. Sustainability of climate change adaptation measures in Rivers State, South-South Nigeria. In W. Leal Filho (ed.), Handbook of Climate Change Resilience, Springer International Publishing AG, part of Springer Nature. 2018, pp. 1-9.

[31] Henri-Ukoha A. \& Walisam A. Adoption of climate smart agricultura practices by smallholder vegetable farmers in Obio-Akpor Local Government Area, AJATE, 2018;7(2):126-137.

[32] Henri-Ukoha A., Ugwuja V.C., Oladejo E.E., Zigakolbari N and Onyenma G. Gender roles in climate change adaptation strategies by cassava-based farmers in Gokana local Government Area of Rivers State, Journal of Agriculture and Food Sciences, 2018;16(1):79-90.

[33] Henri-Ukoha A. Assessment of the viability of climate change adaptation strategies of cassava-based farmers in Southern Nigeria. Journal of Agriculture and Food Sciences, 2020;18(1):105-117.

[34] Henri-Ukoha A. Assessment of the Cost-Benefits of Climate Change Adaptation Strategies of Cassava-Based Farmers in Southern Nigeria. International Journal of Environment and Climate Change, 2020;10(10):99-110. https://doi.org/10.9734/ijecc/2020/v10i1030253.

[35] Anyaoha N.P., Nnadi F.N., Chikaire J., Echetama J.A., Utazi C.O \& Iheanacho R.A. Socio-economic factors influencing climate change adaptation strategies, Net Journal of agricultural science, 2013;1(2):42-43.

[36] Otitoju M.A. \& Enete A.A. Climate Change Adaptation Strategies and Farm-level Efficiency in Food Crop Production in Southwestern, Nigeria. Tropicultura, 2014;32 (3):113-120.
[37] Akinbami C.A.O., Ifeanyi-obi C.C., Appiah D.O. \& Kabo-Bah A.T. Towards sustainable adaptation to climate change: The role of indigenous knowledge in Nigeria and Ghana. African Journal of sustainable development, 2016;6(2):189-214.

[38] Ifeanyi-obi C.C., Togun A.O., Lamboll R. \& Arokoyu S. Socioeconomic determinants of cocoyam farmer's strategies for climate change adaptation in Southeast Nigeria. Journal of Agricultural Extension; 2017b;21(2):91-104.

[39] Enimu S. \& Onome G.E. Determinants of Climate ChangeAdaptation Strategies Among Farm Households in Delta State, Nigeria. Current Investigationsin Agriculture and Current Research, 2018;5(3):663668.

[40] Onyeneke R.U., Nwajiuba C.A., Emenekwe C.C., Nwajiuba A., Onyeneke C.J., Ohalete P., \& Uwazie U.I. Climate change adaptation in Nigerian agricultural sector: A systematic review and resilience check of adaptation measures. AIMS Agriculture and Food, 2019;4(4), 967-1006.

[41] Mckune S.L., Borresen E.C., Young A.G., Auria T.D., Russo S.L. \& Diao A. Climate change through a gendered lens: examining livestock holder food security. Global Food Security, 2015;6:1-8.

[42] Adzawla W., Azumah S.B., Anani P.Y \& Donkoh S.A. Gender perspectives of climate change adaptation in two selected districts of Ghana. Heliyon, 2019;5(11):1-6.

[43] Assan E., Suvedi M., Olabisi L.s and Alen A. Coping with and adapting to climate change: A gender perspective to smallholder farming in Ghana. Environments, 2018;5,86:14-19.

[44] Björnberg K.E. \& Hansson S.O. Gendering local climate adaptation, Local Environ. International Journal of Justice Sustainability, 2013;18(2):217-232

[45] Ajadi A.A., Oladele O.I. \& Ikegami K. Rural women's farmers access to productive resources: the moderating effect of culture among Nupe and Yoruba in Nigeria. Agriculture and Food Security, 2015;4:26. https://doi.org/10.1186/s40066-015-0048-y.

[46] Ajadi A.A., Oladele O.I., Ikegami K. \& Tsuruta T. Rural women's farmers access to productive resources: the moderating effect of culture among Nupe and Yoruba in Nigeria. Agric \& Food Security, 2015;4(26). https://doi.org/10.1186/s40066-015-0048-y.

[47] Azong M., Kelso C. J \&Naidoo K. Vulnerability and resilience of female farmers in Oku, Cameroon, to Climate Change. African Sociological Review, 2018;22(1):31-53. DOI: 10.2307/90023845.

[48] Department for International Development (DFID) policy paper Reducing poverty by tackling social exclusion, 2005.

[49] Beall J \& Piron L. DFID Social exclusion review. London school of Economics and Political science, 2005.

[50] Silver H. The process of social exclusion: the dynamics of an evolving concept. Chronic Poverty Research Centre (CPRC) Working Paper 95, 2007.

[51] Ifeanyi-obi C.C and Ugorji E.C. Effects of social exclusion on climate change adaptation of female arable crop farmers in Abia State, Nigeria. South African Journal of Agricultural Extension, 2020;48(1): 55-69.

[52] Adenugba A.O. \& Raji-Mustapha N. O. The role of women in promoting agricultural productivity and developing skills for improved quality of life in rural areas. IOSR Journal of Engineering (IOSRJEN), 2013;3(8):51-58.

[53] Onyekuru N.A. \& Marchant R. Climate change perception, awareness and adaptation decision among forestcommunities in Nigeria. AgroScience, 2017;16 (3), 51-62.

[54] Birchall J. Legislation, policies and social exclusion in Nigeria Knowledge, evidence and learning for development (K4D) Helpdesk report, 2019

https://opendocs.ids.ac.uk/opendocs/handle/20.500.12413/14810. 